\title{
The Diagnostic Performance of Red Cell Distribution Width and Mentzer Index for Discrimination between Iron Deficiency Anemia and Beta Thalassemia Trait
}

\author{
HANAN S. AHMED, M.Sc.; EKRAM A. HASHEM, M.D.; OSAMA M. AL-ASHEER, M.D. and \\ AMAL A. MAHMOUD, M.D.
}

The Department of Pediatrics, Faculty of Medicine, Assiut University, Assiut, Egypt

\begin{abstract}
Background: Mild microcytic hypochromic anemias due to Iron Deficiency (IDA) and Beta Thalassemia Trait ( $\beta$-TT) continue to be a cause of significant burden to the society, particularly in the poorer developing countries, as $\beta$-TT is often misdiagnosed as iron deficiency anemia in children because the two produce similar hematologic abnormalities on Complete Blood Count (CBC), and IDA is much more prevalent. So it is important to differentiate between thalassemic and non thalassemic microcytosis as both conditions share many characteristics and have important clinical implications. Thus a correct diagnosis in patients with microcytic anemia can provide an indication for supplementing iron to IDA patients, for avoiding unnecessary iron therapy in thalassemia carriers and of course also for preventing severe and lethal forms of thalassemia syndromes in the framework of premarital counseling in high-prevalence areas.
\end{abstract}

Aim of Study: To evaluate the diagnostic performance of simple and costless methods, i.e. red cell distribution width (RDW\%), red cell distribution width index (RDWI) and Mentzer index for discrimination between IDA and $\beta$-TT.

Patients and Methods: The study was conducted on 50 patients with microcytic hypochromic anemia, 26 males and 24 females aged from 2- 4 years recruited from the Hematology Outpatient Clinic. In addition, 15 apparently healthy children with matchable age and sex, selected from relatives of the patients were enrolled in the study as a control group.

Results: The highest sensitivity rate $(100 \%)$ was shown by RDW index but with a low specificity rate, (79.3 1\%) followed by Mentzer as well as Green and King indices with a sensitivity $=95.24 \%$ for each, while the specificity rate of Mentzer index was $93.1 \%$ and that of Green and King index was $79.31 \%$.

Conclusion: Among the studied indices, reduced Mentzer index $<13$ showed the highest diagnostic performance for discrimination between iron deficiency anemia and beta thalassemia trait by detection of increased $\mathrm{Hb} \mathrm{A} 2>3.5 \%$ as proved by ROC test.

Correspondence to: Dr. Hanan S. Ahmed, E-Mail: drsmart8989@Gmail.com
Recommendation: As discrimination between iron deficiency anemia and beta thalassemia trait is very essential to reach the suitable therapeutic strategy for such cases, therefore, we recommend the use of Mentzer index as a feasible, costless method with a high diagnostic performance for preliminary discrimination between those two diseases.

Key Words: Beta Thalassemia Trait-Iron Deficiency Anemia - Mentzer index $-R D W \%-R D W$ index.

\section{Introduction}

MILD microcytic hypochromic anemias due to Iron Deficiency (IDA) and Beta Thalassemia Trait $(\beta-T T)$ continue to be a cause of significant burden to the society, particularly in the poorer developing countries, as $\beta$-TT is often misdiagnosed as iron deficiency anemia in children because the two produce similar hematologic abnormalities on Complete Blood Count (CBC), and IDA is much more prevalent. So it is important to differentiate between thalassemic and non thalassemic microcytosis as both conditions share many characteristics and have important clinical implications. Thus a correct diagnosis in patients with microcytic anemia can provide an indication for supplementing iron to IDA patients, for avoiding unnecessary iron therapy in thalassemia carriers and of course also for preventing severe and lethal forms of thalassemia syndromes in the framework of premarital counseling in high-prevalence areas [1].

Iron Deficiency Anemia (IDA) and beta thalassemia trait ( $\beta$-TT) are the two most frequent disorders presenting clinically with mild microcytic hypochromic anemia [2]. Lack of sufficient dietary iron resulting in IDA is the most common hematological disorder. It has been estimated that $30 \%$ of the world population suffers from IDA with majority of the affected people living in developing 
countries. In $\beta$-TT there is impaired globin chain synthesis resulting in decreased hemoglobin leading to microcytic hypochromic anemia. $1.5 \%$ of world population carries genes for beta thalassemia [3] Thalassemia traditionally has a high prevalence in some parts of the world (Mediterranean regions up to $8 \%$; countries of the Middle East up to 10\%; India 3\%-15\%; Southeast Asia up to 9\%), where it represents a major public health problem. Non endemic countries such as in Northern Europe and North America are also involved in thalassemia related problems as a result of demographic changes caused by migration and intermarriages of different ethnic populations $[4,5]$. Nowadays population migration has spread thalassemia genes over nearly the entire globe [6], so it is important to differentiate between thalassemic and non thalassemic microcytosis as both conditions share many characteristics and have important clinical implications [8] Thus a correct diagnosis in patients with microcytic anemia can provide an indication for supplementing iron to IDA patients, for avoiding unnecessary iron therapy in thalassemia carriers and of course also for preventing severe and lethal forms of thalassemia syndromes in the framework of premarital counseling in high-prevalence areas [1]. A definitive differential diagnosis between $\beta$-TT and IDA is based on the result of $\mathrm{HBA}_{2}$ electrophoresis, serum iron levels, and ferritin calculations [9]. However, these investigations are money and time consuming and moreover the areas where thalassemia is endemic often have low health care resources and these assays may not be generally available [1] Thus, various discrimination indices have been proposed to distinguish between $\beta$-TT and IDA. These indices are derived from several simple Red Blood Cell (RBCs) indices, like RBCs count, Mean Cell Volume (MCV), mean corpuscular hemoglobin $(\mathrm{MCH}), \mathrm{RBCs}$ Distribution Width (RDW) and Hemoglobin $(\mathrm{Hb})$ as these are provided by electronic cell counters [10]. The purpose of using indices to discriminate anemia is to detect subjects who have a high probability of requiring appropriate follow-up and to reduce unnecessary investigative costs [11]. An ideal discrimination index has high sensitivity and specificity; that is, it can detect the maximum number of patients with $\beta$-TT (high sensitivity) while eliminating patients with IDA (high specificity) [11]

\section{Subjects and Methods}

The study was conducted on 50 patients with microcytic hypochromic anemia, 26 males and 24 females aged from 2-4 years recruited from the Hematology Outpatient Clinic, Assuit University Children Hospital, during the period from the 1 st of June, 2016 to the 30 th of May, 2017. In addition, 15 apparently healthy children with matchable age and sex, selected from relatives of the patients were enrolled in the study as a control group.

\section{Inclusion criteria:}

Microcytic hypochromic anemia with hemoglobin level not less than $7 \mathrm{~g} / \mathrm{dl}$.

\section{Exclusion criteria:}

- Hemoglobin level less than $7 \mathrm{~g} / \mathrm{dl}$.

- Chronic disease or infection.

- Lead poisoning.

- History of previous blood transfusion.

Beside meticulous history and thorough clinical examination. All the studied cases and controls were subjected to the following investigations Complete Blood Count (CBC), Blood film, Serum iron, Serum ferritin, Total Iron Binding Capacity (TIBC) and hemoglobin electrophoresis, and the other discrimination indices were calculated by using RBCs indices as defined below:

- Mentzer Index (MI): MCV/RBC [12]:

\section{Interpretation:}

IDA: $>13$.

BTT: $<13$.
- Green and King Index $(G \& K): M C V 2 X R D W /$ $100 \times \mathrm{Hb}$ [13]:

Interpretation:

IDA: $>72$.

BTT: $<72$.

- RDW Index (RDWI): $M C V X R D W / R B C$ [14]:

Interpretation:

IDA: $>220$.

BTT: $<220$.

\section{- Evaluation of red cell distribution width (RDW):}

Red cell distribution width quantitatively measures RBCs size variation, computed directly from the RBCs histogram and is calculated as a standard statistical value, the coefficient of variation of the volume distribution [15]. In general, an elevated RDW has been associated with anemia from various deficiencies such B12, folate or iron [16]. So RDW as a measure of the degree of variation in red cell size, has been reported to be a good discrimination index to differentiate between $3-$ TT and IDA [17]

\section{Interpretation:}

IDA: $>14$.

BTT: $<14$. 
The sensitivity and specificity, and positive and negative predictive values were calculated as follows: Sensitivity: True positive/(true positive + false negative); specificity: True negative/(true negative + false positive); positive predictive value: True positive/(true positive + false positive); negative predictive value: (True negative/true negative + false negative).

\section{Statistical analysis:}

The data were coded and verified prior to data entry. The Statistical Package for Social Science (SPSS) Version 19 (Microsofot Windows, SPSS Inc), was used for data entry and analysis. Data were checked for Gaussian distribution by the Shapiro-Wilk statistic. Parameters with Gaussian distribution were expressed as mean $\pm \mathrm{SD}$; between group differences they were assessed by independent samples $t$-test for parametric data and MannWhitney test for non parametric data. The Chisquare test $\left(\chi^{2}\right)$ was used to compare the frequency of qualitative variables among the studied groups [18].

A $p$-value $>0.05$ was determined as non significant, while $p$-value $<0.05$ was considered significant [18]

The diagnostic performance of RBCs count, $\mathrm{Hb}$ level, HCT value, reticulocytic count, MCV, $\mathrm{MCH}, \mathrm{MCHC}, \mathrm{RDW} \%$, serum iron, serum ferritin and TIBC as well as Mentzer, RDW, Green and King Indices for detection of increased $\mathrm{Hb} \mathrm{A} 2$ serum level $(>3.5 \%)$ among cases with hypochromic microcytic anemia and control group was evaluated using Receiver Operating Characteristic (ROC) curve analysis. The optimal cut off values was determined by Youden index [18]

\section{Results}

The majority of patients in the present study had no obvious complaints related to anemia but weakness followed by fatigue was the next common complaints received. On the basis of $\mathrm{HBA}_{2}$ levels, 21 patients having $\mathrm{HBA}_{2}$ more than $3.5 \%$ were grouped into $\beta$-TT group. The rest 29 patients having $\mathrm{HBA}_{2}$ less than $3.5 \%$ were included in the IDA group.

Table (1) shows significant increase of RBCs count and reticulocytic count among cases with BTT (5.02 \pm 0.42 and $4.89 \pm 2.07$ respectively) compared to cases with iron deficiency anemia (4.32 \pm 0.44 and $1.75 \pm 1.45$ respectively) ( $p<0.001$ for each), significant increase of hemoglobin concentration and hematocrite value among cases with
BTT $(9.27 \pm 1.05$ and $29.18 \pm 3.44$ respectively) compared to cases with iron deficiency anemia $(8.53 \pm 0.98$ and $27.55 \pm 3.59$ respectively) $(p<0.031$ for each). Also, significant increase of RBCs count and reticulocytic count among cases with BTT (5.02 \pm 0.42 and $4.89 \pm 2.07$ respectively) compared to controls ( $4.74 \pm 0.27$ and $1.19 \pm 0.56$ respectively) $(p<0.031$ and $p<0.001$ respectively), while significant decrease of hemoglobin concentration and hematocrite value were found among cases with BTT $(9.27 \pm 1.05$ and $29.18 \pm 3.44$ respectively) compared to controls $(12.19 \pm 0.47$ and $37.41 \pm 1.17$ respectively) ( $p<0.001$ for each). In addition, significant decrease of RBCs count, hemoglobin concentration and hematocrite value were found among cases with iron deficiency anemia (4.32 \pm 0.44 , $8.53 \pm 0.98$ and $27.55 \pm 3.59$ respectively) compared to controls $(4.74 \pm 0.27,12.19 \pm 0.47$ and $37.41 \pm 1.17$ respectively) ( $p<0.001$ for each).

Also it shoos significant decrease of MCV and red cell distribution width among cases with BTT $(58.45 \pm 3.81$ and $13.42 \pm 2.19$ respectively) compared to cases with iron deficiency anemia (63.41 \pm 4.74 and $18.37 \pm 3.37$ respectively) ( $p<0.001$ for each), while significant decrease of $\mathrm{MCV}, \mathrm{MCH}$ and MCHC were found among cases with BTT $(58.45 \pm 3.81,19.26 \pm 2.87$ and $30.20 \pm 2.48$ respectively) compared to controls $(79.68 \pm 4.69,28.13 \pm$ 2.41 and $34.66 \pm 1.75$ respectively) ( $p<0.001$ for each). Also, significant decrease of MCV, MCH and $\mathrm{MCHC}$ were found among cases with IDA $(63.41 \pm 4.74,20.09 \pm 3.33$ and $30.58 \pm 2.09$ respectively) compared to controls $(79.68 \pm 4.69,28.13 \pm$ 2.41 and $34.66 \pm 1.75$ respectively) ( $p<0.001$ for each), while significant increase of red cell distribution width of RBCs was found among cases with IDA $(18.37 \pm 3.37)$ compared to controls (13.33 \pm $0.73)(p<0.001)$.

Cases with BTT showed significant increase of serum iron and serum ferritin $(60.97 \pm 31.09$ and $140.09 \pm 111.57$ respectively) compared to cases with IDA (19.27 \pm 5.70 and $13.05 \pm 6.50$ respectively) ( $p<0.001$ for each), while significant decrease of TIBC value was found among cases with BTT $(287.76 \pm 71.62)$ compared to those with IDA $(497.55 \pm 60.29)(p<0.001)$. Also, significant decrease of serum iron and serum ferritin were found among cases with IDA $(19.27 \pm 5.70$ and $13.05 \pm 6.50$ respectively) compared to controls $(74.20 \pm 22.38$ and71.13 \pm 26.36 respectively) ( $p<0.001$ for each), additionally, significant increase of TIBC value was found among cases with IDA $(497.55 \pm 60.29)$ compared to controls $(271.27 \pm 41.09)(p<0.001)$ as in (Table 1). 
Table (1): Mean values and standard deviation of various hematological and biochemical parameters.

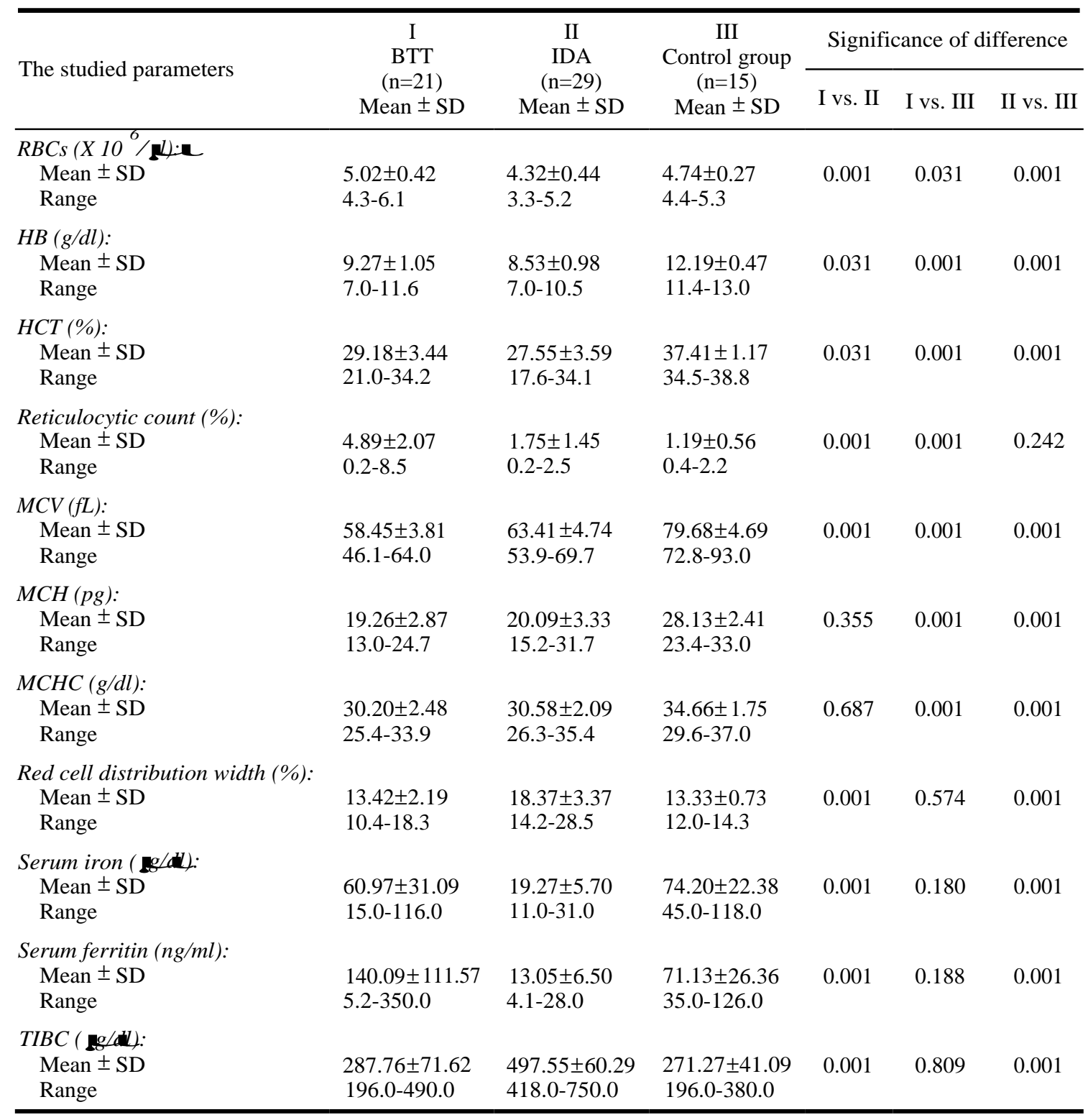

Table (2) shows significant decrease of Mentzer index, RDW index as well as Green and King index among cases with BTT $(11.73 \pm 1.27,156.08 \pm 22.10$ and $49.63 \pm 8.45$ respectively) compared to cases with IDA $(14.85 \pm 2.02,273.85 \pm 71.16$ and $88.03 \pm$ 24.18 respectively) ( $p<0.001$ for each).

Table (2): Values of the studied diagnostic indices in relation to diagnosis of the studied cases.

\begin{tabular}{lllc}
\hline & \multicolumn{1}{c}{$\begin{array}{c}\text { BTT } \\
(\mathrm{n}=21)\end{array}$} & \multicolumn{1}{c}{$\begin{array}{c}\text { IDA } \\
(\mathrm{n}=29)\end{array}$} & $\begin{array}{c}\text { Significance of } \\
\text { difference }\end{array}$ \\
\hline $\begin{array}{l}\text { Mentzer index: } \\
\quad \text { Mean } \pm \mathrm{SD}\end{array}$ & $\begin{array}{l} \\
\end{array}$ & & \\
$\quad$ Range & $8.0-13.73 \pm 1.27$ & $14.85 \pm 2.02$ & 0.001 \\
$R D W$ index: & & $10.8-18.6$ & \\
$\quad$ Mean \pm SD & $156.08 \pm 22.10$ & $273.85 \pm 71.16$ & 0.001 \\
$\quad$ Range & $122.9-209.0$ & $188.4-481.3$ & \\
Green and king index: & & & \\
$\quad$ Mean \pm SD & $49.63 \pm 8.45$ & $88.03 \pm 24.18$ & 0.001 \\
$\quad$ Range & $36.7-73.1$ & $59.4-164.4$ & \\
\hline
\end{tabular}


As regard the predictive values of the studied parameters for detection of increased $\mathrm{HbA}_{2}$ (>3.5\%) Table (3) shows:

- The highest sensitivity rate $(100 \%)$ was shown by RDW index but with a low specificity rate, $(79.31 \%)$ followed by Mentzer as well as Green and King indices with a sensitivity $=95.24 \%$ for each, while the specificity rate of Mentzer index was $93.1 \%$ and that of Green and King index was $79.31 \%$.

- The highest specificity rate $(100 \%)$ was showed by each of RDW\%, serum ferritin, serum iron as well as TIBC which showed the highest sensitivity rate among these parameters $90.48 \%$.

- As regards the +ve and -ve predictive values; RDW\%, serum iron, serum ferritin and TIBC showed the highest positive predictive value in predicting increased $\mathrm{HbA}_{2}(>3.5 \%)$ (100\% for each), but the highest negative predictive value among these parameters was shown by TIBC $(93.5 \%)$. About the negative predictive value, the highest value among all the studied parameters was shown by RDW index (100\%), followed by Mentzer, Green and King indices and TIBC (96.4\%, 95.8\% and $93.5 \%$ respectively).
- A ROC test was done to evaluate the diagnostic performance of the studied parameters for detection of increased $\mathrm{Hb} \mathrm{A} 2(>3.5 \%)$ among cases with microcytic hypochromic anemia and control group (Table 3) and Figs. (1-3), it was found that the optimal cut of values of the studied parameters were $>4.57 \times 10 \%$ fa 2 RBCs, $>8.8 \mathrm{~g} / \mathrm{dl}$ for hemoglobin, $>28.9 \%$ for HCT, $>2.9 \%$ for reticulocytic count, $\leq 61 \mathrm{fL}$ for $\mathrm{MCV}, \leq 20.5 \mathrm{~g} / \mathrm{dl}$ for $\mathrm{MCH}, \leq 29 \mathrm{~g} / \mathrm{dl}$ for $\mathrm{MCHC},<14 \%$ for RDW, $>31$ $\mathrm{g} / \mathrm{d}$ hor serum iron, $>28 \mathrm{~g} / \mathrm{l}$ or ferritin, $\leq 350$ $\mathrm{g} / \mathrm{d}$ for TIBC, <13 for Mentzer index, <220 for RDW index and $<72$ for Green and King index.

- Total iron binding capacity showed the highest value of AUC (0.973) among the studied parameters with $95 \%$ CI 0.882-0.998, followed by serum iron, serum ferritin and Mentzer index $(0.954,0.943$ and 0.942 respectively) with $95 \%$ CI (0.854-0.993, 0.839-0.989 and 0.837-0.988 respectively).

- Concerning the diagnostic accuracy (ACC) for detection of increased $\mathrm{HbA}_{2}(>3.5 \%)$, TIBC showed the highest ACC (96\%) with $95 \%$ CI (92.7-99.3) followed by serum iron, serum ferritin and Mentzer index (94\% for each) with $95 \% \mathrm{CI}$ (91-97, 91.8-96.2 and 91.5-96.2 respectively).

Table (3): Diagnostic performance of the studied parameters and indices for detection of increased HbA 2 serum level (>3.5\%) among cases with microcytic hypochromic anemia and control group.

\begin{tabular}{|c|c|c|c|c|c|c|c|c|c|}
\hline $\begin{array}{l}\text { The studied parameters } \\
\text { and indices }\end{array}$ & $\begin{array}{l}\text { Optimal cut } \\
\text { of value }\end{array}$ & $\begin{array}{c}\text { Sensitivity } \\
\%\end{array}$ & $\begin{array}{l}\text { Specificity } \\
\%\end{array}$ & $\begin{array}{c}\mathrm{PPV} \\
\%\end{array}$ & $\begin{array}{c}\mathrm{NPV} \\
\%\end{array}$ & AUC & $\begin{array}{l}95 \% \text { CI } \\
\text { of AUC }\end{array}$ & $\underset{\%}{\mathrm{ACU}}$ & $\begin{array}{l}95 \% \mathrm{CI} \\
\text { of ACC }\end{array}$ \\
\hline \multicolumn{10}{|l|}{ The parameters: } \\
\hline $\operatorname{RBC}\left(10^{6} / 1\right)$ & $>4.57$ & 90.48 & 79.31 & 76.0 & 92.0 & 0.895 & $0.775-0.964$ & 84.00 & $81.9-86.1$ \\
\hline $\mathrm{Hb}(\mathrm{g} / \mathrm{dl})$ & $>8.8$ & 71.43 & 72.41 & 65.2 & 77.8 & 0.680 & 0.533-0.805 & 72.00 & $71.3-73.7$ \\
\hline $\operatorname{HCT}(\%)$ & $>28.9$ & 71.43 & 72.41 & 65.2 & 77.8 & 0.680 & $0.533-0.805$ & 72.00 & $70.5-73.5$ \\
\hline $\operatorname{RET}(\%)$ & $>2.9$ & 90.48 & 89.66 & 86.4 & 92.9 & 0.903 & $0.786-0.969$ & 90.00 & $86.3-93.2$ \\
\hline MCV (fL) & $\leq 61$ & 85.71 & 72.41 & 69.2 & 87.5 & 0.782 & $0.643-0.887$ & 78.00 & $76.5-79.5$ \\
\hline $\mathrm{MCH}(\mathrm{pg})$ & $\leq 20.5$ & 80.95 & 51.72 & 54.8 & 78.9 & 0.577 & $0.429-0.716$ & 64.00 & $62.8-65.2$ \\
\hline $\mathrm{MCHC}(\mathrm{g} / \mathrm{dl})$ & $\leq 29$ & 47.62 & 79.31 & 62.5 & 67.6 & 0.534 & $0.387-0.676$ & 66.00 & $64.5-67.5$ \\
\hline RDW (\%) & $<14$ & 71.43 & 100.00 & 100.0 & 82.9 & 0.857 & $0.729-0.940$ & 88.00 & $85.9-90.1$ \\
\hline Serum Iron $(\mathrm{g} / \mathbf{d})$ & $>31$ & 85.71 & 100.00 & 100.0 & 90.6 & 0.954 & $0.854-0.993$ & 94.00 & $91-97$ \\
\hline Serum Ferritin $(\mathrm{g} / \mathrm{d}$ & $>28$ & 85.71 & 100.00 & 100.0 & 90.6 & 0.943 & 0.839-0.989 & 94.00 & $91.8-96.2$ \\
\hline TIBC $(\mathrm{g} / \mathbf{d})$ & $\leq 350$ & 90.48 & 100.00 & 100.0 & 93.5 & 0.973 & $0.882-0.998$ & 96.00 & $92.7-99.3$ \\
\hline \multicolumn{10}{|l|}{ The indices: } \\
\hline Mentzer index & $<13$ & 95.24 & 93.10 & 90.9 & 96.4 & 0.942 & $0.837-.988$ & 94.00 & $91.5-96.2$ \\
\hline RDW index & $<220$ & 100.00 & 79.31 & 77.8 & 100.0 & 0.897 & $0.778-0.965$ & 88.00 & $83.7-90.3$ \\
\hline Green and King index & $<72$ & 95.24 & 79.31 & 76.9 & 95.8 & 0.873 & $0.748-0.950$ & 86.00 & $83.7-88.3$ \\
\hline $\begin{array}{l}\text { AUC : Area Under Curve. } \\
\text { ACC : Accuracy. } \\
\text { PPV : Positive Predictive } \\
\text { NPV : Negative Predictive } \\
95 \% \text { CI }: 95 \% \text { confidence int }\end{array}$ & ue. & & & & & & & & \\
\hline
\end{tabular}




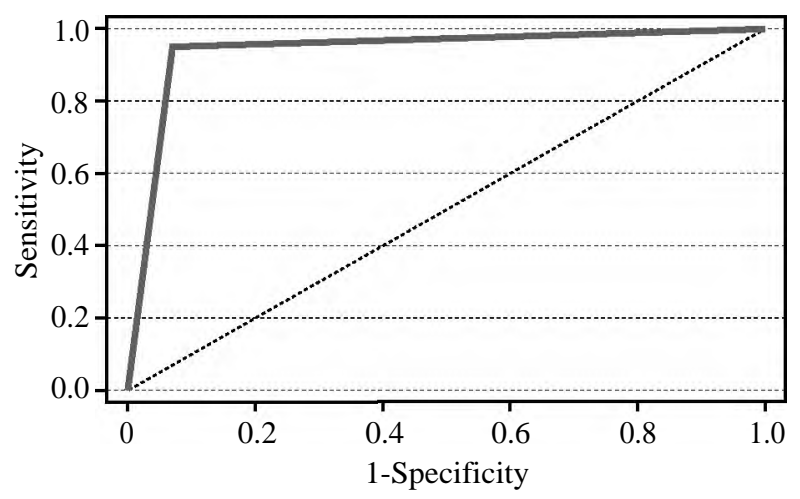

Fig. (1): Receiver Operating Characteristic (ROC) curve to determine the diagnostic performance of Mentzer index for detection of increased $\mathrm{Hb}$ A2 serum level $(>3.5 \%)$ among the studied caseswith hypochromic microcytic anemia and control group.

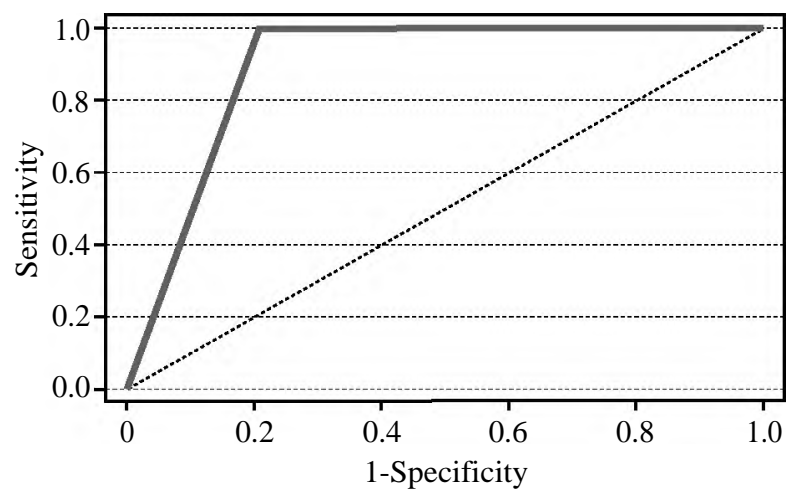

Fig. (2): Receiver Operating Characteristic (ROC) curve to determine the diagnostic performance of RDW index for detection of increased $\mathrm{HbA}_{2}$ serum level $(>3.5 \%)$ among the studied caseswith hypochromic microcytic anemia and control group.

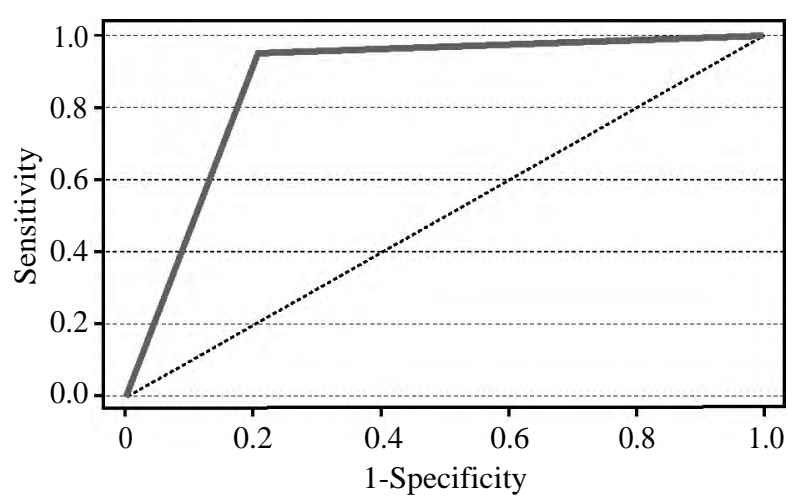

Fig. (3): Receiver Operating Characteristic (ROC) curve to determine the diagnostic performance of Green and King index for detections of increased $\mathrm{HbA}_{2}$ serum level (>3.5\%) among the studied caseswith hypochromic microcytic anemia and control group.

\section{Discussion}

In the present study, patient with BTT showed significant increase in RBCs count $(5.02 \pm 0.42 \mathrm{X}$ $10^{6 / L}$ ) ompared to those with IDA $(4.32 \pm 0.44$ X $10^{6} /$ C nd this was in agreement with Piplani et al., [11] who found that, majority of patients with BTT in their study had a high RBCs count of more than 5 million with mean value $(5.79 \pm 0.76 \times 106 /$ L) comparison to IDA $\left(4.77 \pm 0.53 \times 10^{6} / \mathbf{L}\right)$ Vehapoglun et al., [20] also stated that, RBCs count was higher in the BTT $\left(5.56 \pm 0.4 \times 10^{6 /}\right)$ goup than that in the IDA $\left(4.84 \pm 0.59 \times 10^{6} / p_{0}<05\right)$. Red blood cells count tends to be higher in BTT than in IDA. This increase in RBCs count can be explained by Globin chain precipitation in erythroid precursor cells and circulating erythrocytes that leads to a discrete inefficacious erythropoiesis, causing increased erythrocyte production in an attempt to compensate for anemia (hyper active bone marrow). From these result they concluded that, $\mathrm{RBC}$ count alone cannot be taken as a reliable index to distinguish between of BTT and IDA as a high erythrocyte count $(\mathrm{RBC}>5.0 \times 10 \%$ (C) a common feature of IDA and BTT.

In our studied cases there were significant increase of hemoglobin concentration among cases with BTT $(9.27 \pm 1.05 \mathrm{gm} / \mathrm{dl})$ compared to cases with iron deficiency anemia $(8.53 \pm 0.98 \mathrm{gm} / \mathrm{dl})$ this is in agreement with Nesa et al., [21] who found the mean hemoglobin level $(10.2 \pm 0.8 \mathrm{gm} / \mathrm{dl})$ in cases of BTT, and $(9.8 \pm 0.9 \mathrm{gm} / \mathrm{dl})$ in case of IDA, similar results were also found by matos et al., [22] who found significant differences of $\mathrm{Hb}$ level between BTT and IDA. On the other hand Piplani et al., and Vehapoglu et al., [11,20] found that the mean values for $\mathrm{Hb}$ in BTT were $10.39 \pm 0.69$ and $10.7+0.8$ respectively and those in the IDA group were $10.23 \pm 0.95$ and $9.9 \pm 1.43$ respectively $(p>0.05)$ with no significance of differences between them, and they concluded that, hemoglobin count cannot be taken as a reliable index to distinguish between BTT and IDA.

Data of the present study showed significant increase in reticulocytic count among the studied cases with BTT $(4.89 \pm 2.07 \%)$ compared to cases with IDA $(1.75 \pm 1.45 \%)$, and this is in agreement with Noronha and Grotto, [23] who found significant increase in reticulocytic count in patients with BTT than those with IDA. The number of reticulocytes in the peripheral blood is fairly accurate reflection of erythropoietic activity and is an indicator of the erythropoitic activity of bone marrow which is more in patients with BTT.

Our data showed significant decrease of MCV among studied cases with BTT $(58.45 \pm 3.81 \mathrm{fL})$ compared to studied cases with iron deficiency anemia $(63.41 \pm 4.74 \mathrm{fL})$, this is in agreement with the previous studies Piplani et al., [11], Nesa et al., [21], Matos et al., [22] and Ntaios et al., [24] who 
found that MCV tend to be lower in BTT compared to IDA with significance of differences $<0.05$. This was explained by significant increase in RBCs count in BTT than IDA with no significant of difference for HCT among cases with BTT compared to cases with IDA as MCV equal to packed red cell volume divided by RBCs count by millions, and this explains the importance of MCV values as discriminating parameters but using it alone not sufficient to differentiate between BTT and IDA due to low sensitivity and specificity.

Our results show significant decrease of RDW\% among cases with BTT (13.42 $\pm 2.19 \%)$ compared to those with iron deficiency anemia (18.37 \pm $3.37 \%$ ), with sensitivity $71.43 \%$, specificity $100.00 \%$ AUC 0.857 and ACC $88.00 \%$, this is in agreement with Rahim and Keikhaei, [25] who found that, significant decrease of RDW\% was observed between the groups with BTT (11.79 \pm $6.75 \%)$ compared to IDA $(14.20 \pm 4.2 \%)$ with sensitivity $51 \%$, specificity $87 \%$ for BTT and for IDA sensitivity $87 \%$ and specificity $51 \%$, Matos et al., [22] also found that, significant decrease of RDW\%

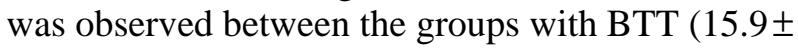
$0.5 \%)$ compared to IDA $(17.9 \pm 1.2 \%)$.

Red cell distribution width was first described by Bessman and Feinstein, [26] as parameters used for discrimination between BTT and IDA, and nowadays is part of automated counter analyses. Bessman and Feinstein, [26] observed that erythrocytes of thalassemia minor patients were more homogeneous than those of iron deficiency anemia patients. Consequently, RDW\% tends to be higher in IDA than in BTT [26].

On the other hand Nesa et al., [21] found that RDW\% more or less equally elevated in BTT and IDA the mean value of RDW\%, found in IDA and BTT were $16.9 \pm 2.9$ SD and $16.4 \pm 2.5$ SD respectively with sensitivity $17.5 \%$ and specificity $84.7 \%$ for BTT, and sensitivity $84.7 \%$ and specificity 17.5 for IDA. Similar findings to Nesa et al., [21] were also reported by Ntaios et al., [24] Flynn et al., [27], Bagar et al., [28] and AlFadhli et al., [29], concluded that, a correct discrimination between these disorders could not be done based on just RDW\%. Besides those studies, Matos et al., [22] did not verify significant difference in RDW\% between the three groups of assessed microcytic anemias (IDA, BTT and anemia of chronic disease), indicating that this test has limited usefulness for differentiating iron deficiency anemia, beta thalassemia minor, and anemia of chronic disease [22]
In the present study, the studied cases showed significant increase of serum iron and serum ferritin among the studied cases with BTT $(60.97 \pm 31.0$ and $140.09 \pm 111.579$ respectively) compared to the studied cases with IDA (19.27 \pm 5.70 and $13.05 \pm 6.50$ respectively), similar findings were also reported by Rahim and Keikhaei, [25] and Piplani et al., [11] who found significante increase of serum iron and serum ferritin among the studied cases with BTT $(75.8 \pm 29.1$ and $31.09 \pm 6.79$ respectively) and (78.2 \pm 18.3 and $36.1 \pm 18.4$ respectively) compared to the studied cases with IDA $(20.03 \pm 8.01$ and $4.23 \pm 2.01$ respectively) and ( $21.1 \pm 9.4$ and $6.92 \pm 2.9$ respectively). Taken in consideration that serum iron is non specific in the differentiation between patient with BTT and patient with IDA due to it is diurnal variation and patients with BTT have ineffective erythropoiesis due to imbalanced synthesis of globin chains and increase of total erythropoisis and plasma iron turnover leads to increased iron absorption, so it is considered as non significant parameter in differentiation between BTT and IDA.

Serum ferritin test is done for evaluating iron deficiency anemia as the ferritin levels measured usually have a direct correlation with the total amount of iron stored in the body. However, the result must be interpreted with caution in any patient with an underlying inflammatory process, as ferritin is an acute phase reactant, and is increased when an acute or chronic inflammatory process is present [30]

In our studied cases TIBC which is a parameter related to iron deficiency was found significantly decreased among the cases with BTT (287.76 \pm 71.62) compared to cases with IDA (497.55 \pm 60.29$)$ with sensitivity $90.48 \%$ and specificity $100.00 \%$. This in agreement with Rahim and Keikhaei, [25] and Demir et al., [31] who found that, significant decrease of TIBC level was found among cases with BTT (431.9 \pm 72.2 and $321.7 \pm 36.8$ respectively) compared to cases with IDA (334.6 \pm 49.6 and 378.6 \pm 70.01 ) respectively. On the other hand Vehapoglu et al., [20] found, no significant differences between cases with BTT (339 440.47$)$ compared to those with IDA (392 \pm 41.74$)$.

Total iron-binding capacity measures the availability of iron binding sites. Extracellular iron is transported in the body bound to transferrin, a specific carrier protein. Hence, TIBC indirectly measures transferrin levels, which increase as serum iron concentration (and stored iron) decreases [32]. 
Considering RBCs indices, our study showed significant decrease of RDW index among cases with BTT (156.08 \pm 22.10$)$ compared to cases with IDA (273.85 \pm 71.16$)$, with sensitivity $100 \%$, specificity $79.31 \%$ AUC 0.897 and accuracy $88 \%$. This is in agreement with Nesa et al., [21] who found that RDWI came out as good discriminator between BTT and IDA, with sensitivity $80.7 \%$ and specificity $84.7 \%$ in detection of BTT. And for detection of IDA were found $84.7 \%$ sensitivity and $80.7 \%$ specificity. These results are consistent with the findings of Demir et al., [31] and Sirdah et al., [33] who stated that, RDWI appears to be one of reliable and useful indices for initial screening of microcytic hypochromic anemia and is better than RDW\% in differentiating IDA from BTT but is not the most reliable one as said by, Rahim and Keikhaei, [25] found that RDW index was one of the reliable indices in differentiation between BTT and IDA with sensitivity (97\% and 71\%) and specificity ( $71 \%$ and $97 \%$ ) for BTT and IDA respectively but not the best one as Mentzer index was better than it with sensitivity (93\% and $85 \%$ respectively) and specificity ( $85 \%$ and $93 \%$ respectively) for BTT and IDA, Piplani et al., [11] found that RDW index sensitivity $(80.5 \%$ and $77.7 \%$ respectively) and specificity ( $77.7 \%$ and $80.5 \%$ respectively) for BTT and IDA respectively but was not the best one as Mentzer index was better than it with sensitivity $(94.4 \%$ and $86.9 \%$ respectively) and specificity $(86.9 \%$ and $94.4 \%$ respectively) for BTT and IDA respectively. Same result also had been found by Vehapoglu et al., [20] who found that, sensitivity of Mentzer index was $(98.7 \%$ and $82.3 \%$ repectively) and specificity $(82.3 \%$ and $98.7 \%$ respectively) for BTT and IDA and is better than RDWI with sensitivity $(83.1 \%$ and $76.4 \%$ respectivly) and specificity (76.4\% and $83.1 \%$ respectively) for differentiation between BTT and IDA respectively.

Our study showed significant decrease of Green and King index among the studied cases with BTT $(49.63 \pm 8.45)$ compared to the studied cases with IDA (88.03 \pm 24.18$)$, with sensitivity $95.24 \%$, specificity $79.31 \%$, AUC 0.873 and accuracy $86.00 \%$. This is in agreement with the previous studies done by Ntaios et al., [24] who found that, Green and King proved to be a reliable index, as it had sensitivity $75.06 \%$, specificity $95.8 \%$, efficiency $80.12 \%$ for the detection of BTT, a similar result for the Green and King index was found by Urrechaga et al., [34] and Ferrara et al., [35] who found that, the Green and King index had the highest efficiency (80.2\%) however, its validity is much lower compared to the original study on $\mathrm{G} \& \mathrm{~K}$ by its authors, where the sensitivity of the index was $100 \%$ [13] On the other hand Piplani et al., [11] found the sensitivity of this index was $79.2 \%$ and it showed a low specificity $69.9 \%$ ruling it out as a reliable indicator.

Our data showed significant decrease of Mentzer index among cases with BTT (11.73 \pm 1.27) compared to cases with IDA (14.85 \pm 2.02$)$, with sensitivity $95.24 \%$, specificity $93.1 \%$, AUC 0.942 and accuracy $94.00 \%$, this with is in agreement with Piplani et al., [11] who found that, Mentzer index showed a reasonably high sensitivity $94.4 \%$ and specificity $86.9 \%$ in differentiation between BTT and IDA. Ehsani et al., [36] stated that, the best discrimination index for differentiation between BTT and IDA is Mentzer index with sensitivity $95.5 \%$ and specificity $94.6 \%$ for BTT, and sensitivity $94.6 \%$ and specificity $95.5 \%$ for IDA. Vehapoglu et al., [20] also found that Mentzer index had the high sensitivity $98.7 \%$, specificity $82.3 \%$ for correctly distinguishing BTT and IDA. When the Mentzer index was calculated, $91 \%$ of children with microcytic anemia were correctly diagnosed. Rahim and Keikhaei, [25] also found that, Mentzer index had $85 \%$ sensitivity and $93 \%$ specificity. Similar results of Mentzer index sensitivity $90.9 \%$ and specificity $80.3 \%$ were found by Ghafouri et al., [37] . In contrast Demir et al., [31] found that, sensitivity of Mentzer index (62\% and $86 \%$ ) and it is specificity ( $86 \%$ and $62 \%$ ) for BTT and IDA respectively, and according to their results Mentzer index cannot be considered as one of the reliable indices and RDW index followed by RBCs count are better than it. Also, Sirdah et al., [33] found that the most reliable indices for differentiation between BTT and IDA are Green and King index followed by RDW index. According to Ntaios et al., [24] Green and King shows the highest reliability, followed by England and Fraser, RBC count, Mentzer index, and RDW index.

\section{Conclusion:}

Among the studied indices, reduced Mentzer index $<13$ showed the highest diagnostic performance for discrimination between iron deficiency anemia and beta thalassemia trait by detection of increased $\mathrm{HbA}_{2}>3.5 \%$ as proved by ROC test. While among the studied parameters, TIBC $\leq 350$ d/lashowed the highest diagnostic performance for this discrimination, as proved also by ROC test.

\section{Financial support and sponsorship:}

Nil. 


\section{Recommendations:}

As discrimination between iron deficiency anemia and beta thalassemia trait is very essential to reach the suitable therapeutic strategy for such cases, therefore, we recommend the use of Mentzer index as a feasible, costless method with a high diagnostic performance for preliminary discrimination between this two diseases.

\section{References}

1- HOFFMANN J. J.M.L., ELOÍSA URRECHAGA E. and AGUIRRE U.: Discriminant indices for distinguishing thalassemia and iron deficiency in patients with microcytic anemia: A meta-analysis. Clin. Chem. Lab. Med., 53 (12): 1883-94, 2015.

2- BRITTENHAM G.M.: Disorders of iron metabolism: Iron deficiency and overload. In: Hoffman R., Benz E.J. Jr., Shattil S.J., et al. (eds) Hematology basic principles and practice, 2nd edn. Churchill Livingstone, New York, 1995.

3- RATHOD D.A., KAUR A., PATEL V. PATEL K., KABRAWALA R., PATEL V., PATEL M. and SHAH P.: Usefulness of cell counterbased parameters and formulas in detection of 3 -thalassemia trait in areas of high prevalence. American Journal of Clinical Pathology, 128 (4): 585-9, 2007.

4- ANGASTINIOTIS M. and MODELL B.: Global epidemiology of hemoglobin disorders. Ann. N. Y. Acad. Sci., 850: 251-69, 1998.

5- WEATHERALL D.J. and CLEGG J.B.: Inherited haemoglobin disorders: An increasing global health problem. Bull World Health Organ., 79: 704-12, 2001.

6- MILMAN N.: Anemia-still a major health problem in many parts of the world! Ann. Hematol., 90: 369-77, 2011.

7- LOKESHWAR M.R., SHAH N., KANAKHIYA S. and MANGLANI M.: Thalassemia. In: IAP Textbook of Paediatrics. 4th edition. Parthasarthy A., Menon P.S.N., Agarwal R.K., et al. (eds): Jay Pee Brothers Medical Publishers Pvt Limited, New Delhi, 794-815, 2009.

8- HALLBERG L.: Iron requirements: Comments on methods and some crucial concepts in iron nutrition. Biol. Trace. Elem. Res., 35: 25-45, 1992.

9- THOMAS C. and THOMAS L.: Biochemical markers and hematologic indices in the diagnosis of functional iron deficiency. Clinical Chemistry, 48 (7): 1066-76, 2000.

10- NTAIOS G., CHATZINIKOLAOU A., SAOULI Z., et al.: Discrimination indices as screening tests for 3 thalassemic trait. Ann. Hematol., 86: 487-91, 2007.

11- PIPLANI S., MADAN M., MANNAN R., MANJARI M., SINGH T. and Lalit M.: Evaluation of Various Discrimination Indices in Differentiating Iron Deficiency Anemia and Beta Thalassemia Trait: A Practical Low Cost Solution. Annals of Pathology and Laboratory Medicine, Vol. 03, No. 06, (Suppl) December, 2016.

12- MENTZER W.C.: Differentiation of iron deficiency from thalassaemia trait. Lancet, 1: 882, 1973.

13-GREEN R. and KING R.: A new red blood cell discriminant incorporating volume dispersion for differentiating iron deficiency anemia from thalassemia minor. Blood Cells, 15: 481-95, 1989.

14- JAYABOSE S., GIAVANELLI J., LEVENDOGLUTUGAL O., SANDOVAL C., ÖZKAYNAK F. and VISINTAINER P.: Differentiating iron deficiency anemia from Thalassemia minor by using an RDW-based index. J. Pediatr. Hematol., 21: 314, 1999.

15- ASLAN D., GUMRUK F., GURGEY A. and ALTAY C.: Importance of RDW Value in Differential Diagnosis of Hypochrome Anaemias. American Journal of Hematology, 69: 31-3, 2002.

16-NICOLL D. et al.: Pocket Guide to Diagnostic Tests (Fifth Edition). New York, NY: The McGraw-Hill Companies, 2008.

17- CLARKE G. and HIGGINS T.: Laboratory investigation of hemoglobinopathies and thalassemia: Review and update. Clin. Chem., 46: 1284-90, 2000.

18- TILAKI K.H.: Receiver Operating Characteristics (ROC) curve analysis for medical diagnostic test evaluation. Caspian JIntern. Med. Spring, 4 (2): 627-35, 2013.

19- UOTILA M., RUOSLAHTI E. and ENGVALL E.: J. Immunol. Methods, 42: 11, 1981.

20- VEHAPOGLU A., OZGURHAN G., DEMIR A., NURSOY A., et al.: Hindawi Publishing Corporation Anemia Volume, Article ID 576738, 7 pages http: //dx. doi. org/ 10.1155/2014/576738, 2014.

21- NESA A., TAYAB M.M., SULTANA T., et al.: Indices and formulas in the differentiation of the $b$ thalassaemia minor from iron deficiency in Palestinian population. Int. J. Lab. Hem., 30: 324-30, 2008.

22- MATOS F.J., BORGES G.B., FERNANDES M.S., FARIA R.J. and CARVALHO G.M.: J. Bras. Patol. Med. Lab., V. 51, N. 1, p. 22-7, February, 2016.

23- NORONHA J.F. and GROTTO H.Z.: Measurement of reticulocyte and red blood cells indices in iron deficiency anemia and beta thalassemia minor, Clin. Chem. Lab. Med., 43 (2): 195-7, 2005.

24- NTAIOS G. and CHATZINIKOLAOU A.: Red cell distribution width in iron deficiency anemia and 3 -thalassemia minor. Am. J. Clin. Pathol., 130: 313-4, 2008.

25- RAHIM F. and KEIKHAEI B.: Better differential diagnosis of iron deficiency anemia from beta-thalassemia trait. Turkish Journal of Hematology, 26 (3): 138-45, 2009.

26- BESSMAN J.D. and FEINSTEIN D.I.: Quantitative anisocytosis as a discriminant between iron deficiency and thalassemia minor. Blood, 53: 288-93, 1979.

27- FLYNN M.M., REPPUN T.S. and BHAGAVAN N.V.: Limitations of red blood cell distribution width (RDW) in evaluation of microcytosis. Am. J. Clin. Pathol., 85: 445-9, 1986.

28- BAGAR M.S., KHURSHID M. and MOLLA A.: Does red blood cell distribution width (RDW) improve evaluation of microcytic anemias. J. Pak. Med. Assoc., 43 (8): 149-51, 1993

29- ALFADHLI S.M., AL-AWADHI A.M. and ALKHALDI D.: Validity Assessment of Nine Discriminant Functions Used for the Differentiation between Iron Deficiency Anemia and Thalassemia Minor. J. Trop. Pediatr., 53: 937, 2006. 
30- AROSIO P. and LEVI S.: "Ferritin, iron homeostasis, and oxidative damage". Free Radical Biology \& Medicine 33 (4): 457-63. Doi: 10.1016/s 0891-5849 (02) 008420.PMID 12160928, Aug., 2002.

31- DEMIR A., YARAL1 N., F1SG1N T., DURU F. and KARA A.: "Most reliable indices in differentiation between thalassemia trait and iron deficiency anemia," Pediatrics International, Vol. 44, No.6, pp. 612-6, 2002.

32- IRWIN GROSS: "Laboratory Studies in the Diagnosis of Iron Deficiency, Latent Iron Deficiency and Iron Deficient Erythropoiesis" Eastern Maine Medical Center, 2004.

33- SIRDAH M., TARAZI I., NAJJAR E.A. and HADDAD R.A.: Evaluation of the diagnostic reliability of different indices and formulas in the differentiation of the $b$ thalassaemia minor from iron deficiency in Palestinian population. Int. J. Lab. Hem., 30: 324-30, 2008.

34- URRECHAGA E., BORQUE L. and ESCANERO J.F. The role of automated measurement of RBC subpopula- tions in differential diagnosis of microcytic anemia and (3-thalassemia screening. American Journal of Clinical Pathology, 135 (3): 374-9, 2011.

35- FERRARA M., CAPOZZI L., RUSSO R., BERTOCCO F. and FERRARA D.: "Reliability of red blood cell indices and formulas to discriminate between 3 thalassemia trait and iron deficiency in children,"Hematology, Vol. 15, No. 2, pp. 112-5, 2010.

36- EHSANI M.A., SHAHGHOLI E., RAHIMINEJAD M.S., SEIGHALI F. and RASHIDI A.: A new index for discrimination between iron deficiency anemia and betathalassemia minor: Results in 284 patients. Pakistan Journal of Biological Sciences, 12 (5): 473-5, 2009.

37- GHAFOURI M., SEFAT L.M. and SHARIFI L.: Comparison of cell counter indices in differention of beta thalassemia trait and iron deficiency anemia. The Scientific Journal of Iranian Blood Transfusion Organization, 2 (7): 385-9, 2006.

\section{الآداء التشخيصى لنطاق توزيع الخالايا الحمراء ومؤشر منتزر (Mentzer) للتمييز بين آنيميا نقص الحديد الفيد وسمة الثمايلاثيميا بيتا}

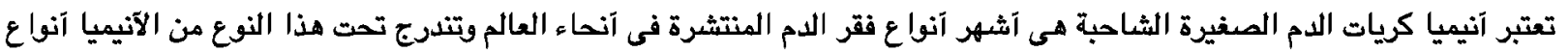
آخرى إما آن تككن قداثية مثل آنيميا البحر المتوبسط وبعض آمراض الهيموجلوبين آو مكتسبة كآنيميا نقص الحديد.

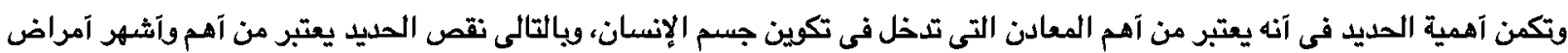

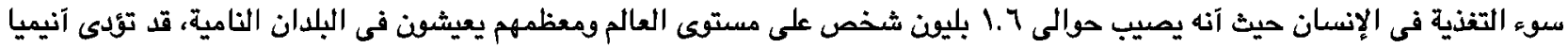

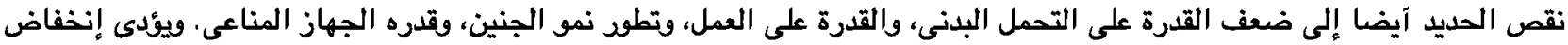

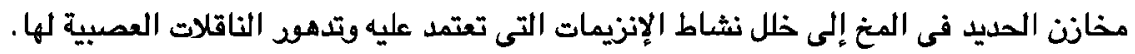

آما آنيميا البحر الآبيض المتوبسط فهى آحد آمراض فقر الدم المزمنة، التى تؤثخ على صنع كريات الدم الحمراء، فتكن مادة الهيموجلوبين

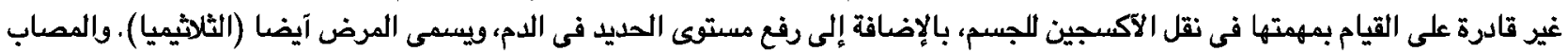

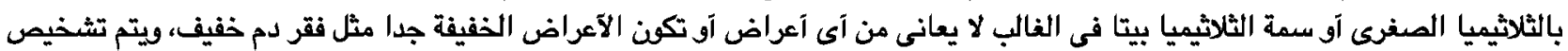

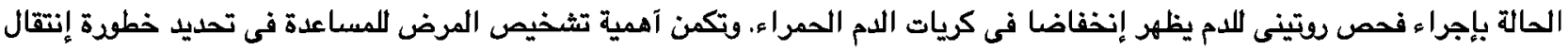

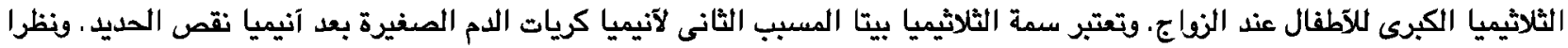

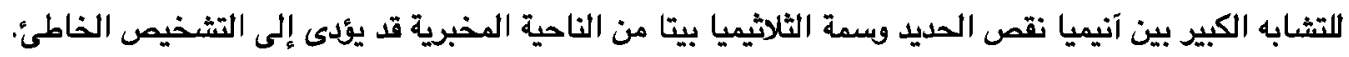

تقييم الآداء التثخيصى لأسياليب بسيطة وغير مكلفة وهى عرض تونزيع الخلايا الحمراء (RDWI)، ومؤشر عرض توزيع الخلايا الحمراء

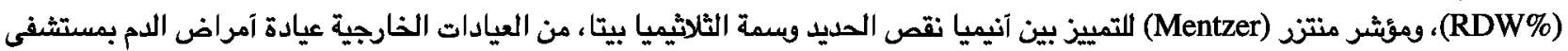

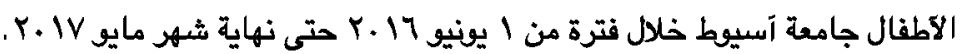

آظهر مؤشر منتز (Mentzer) من بين المؤشرات المدروسة، آعلى آداء تشخيصى فى التمييز بين آنيميا نقص الحديد وسمة الثلاثيميا

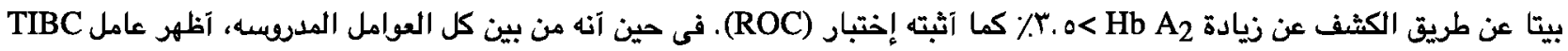

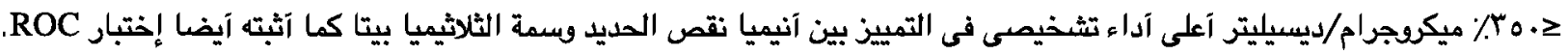

